\author{
Andrzej Kielian ${ }^{1}$ \\ Uniwersytet Papieski Jana Pawła II w Krakowie \\ Barbara Witos ${ }^{2}$ \\ Uniwersytet Papieski Jana Pawła II w Krakowie
}

\title{
Społeczne, etyczne i religijne postawy polskiej młodzieży oraz ich konsekwencje dla nauczania religii w Polsce
}

Piesze, rowerowe, a ostatnio także rolkowe pielgrzymki do Częstochowy z różnych części Polski to niezwykle liczne manifestacje wiary ludzi młodych. Spotkania dla młodzieży, organizowane przez zakony i diecezje w wielu sanktuariach, to kilkudniowe wydarzenia, w których bierze udział kilkanaście tysięcy młodych ludzi z całej Polski. Wakacje w Polsce to czas

1 Ks. Andrzej Kielian - doktor nauk teologicznych w zakresie katechetyki, redaktor podręczników do nauczania religii w przedszkolu i szkole podstawowej, współautor filmów i gier dydaktycznych, adiunkt w Instytucie Teologii Praktycznej Wydziału Teologicznego Uniwersytetu Papieskiego Jana Pawła II w Krakowie, członek Polskiego Towarzystwa Teologicznego w Krakowie. Jego zainteresowania naukowe wiążą się z systemami nauczania religii w Unii Europejskiej, nowymi metodami przekazu wiedzy religijnej oraz z katechezą ewangelizacyjną. E-mail: andrzej.kielian@upjp2.edu.pl.

2 Barbara Witos - mgr lic. teologii, katechetka w Zespole Szkół Łączności w Krakowie. Absolwentka studiów podyplomowych z franciszkanizmu na Wydziale Teologicznym Uniwersytetu Papieskiego Jana Pawła II w Krakowie i doktorantka tegoż wydziału. Dotychczasowe publikacje: Freski o tematyce maryjnej z katakumb św. Pryscylli jako zapis wczesnochrześcijańskiej pobożności,„Polonia Sacra” 18 (2014), nr 4 (37); Osoba św. Melanii Młodszej w świetle „Vita Sanctae Melaniae Senatricis Romae” autorstwa Geroncjusza, „Polonia Sacra” 19 (2015), nr 3 (40). E-mail: bwitos@interia.pl. 
bardzo intensywnych przeżyć religijnych. Dochodzą do tego wyjazdy rekolekcyjno-wypoczynkowe organizowane przez ruchy i stowarzyszenia katolickie, głównie przez Ruch Światło-Życie. Jak na tym tle zarysować społeczny, moralny i religijny portret polskiej młodzieży? Czy jest aż tak dobrze? W jakim stopniu Kościół w Polsce postrzega młodzież jako swoją nadzieję i zarazem wyzwanie? Jan Paweł II w liście do młodych całego świata Parati semper podkreślał, że to właśnie młodzież jest nadzieją Kościoła: „W was jest nadzieja, ponieważ wy należycie do przyszłości, a zarazem przyszłość do was należy"3. Dlatego proces formacji chrześcijańskiej młodzieży stanowi sprawę wielkiej wagi - sprawę przyszłości.

W niniejszym przedłożeniu w pierwszej części zostanie syntetycznie zarysowany obraz dzisiejszego społeczeństwa, ze szczególnym zwróceniem uwagi na niebezpieczeństwa przemian, które zachodzą i wpływają na postawy etyczne i religijne polskiej młodzieży. W drugiej części zostaną przedstawione najistotniejsze aspekty portretu etycznego młodych Polaków. W kolejnej części przeprowadzona będzie analiza sytuacji religijnej polskiej młodzieży. Ostatnia, czwarta część ukaże wnioski dotyczące ewangelizacji i katechizacji młodzieży w Polsce. Opis i analiza postaw zostaną przeprowadzone według metodologii teologii pastoralnej. Głównym źródłem i podstawą do prezentowanych analiz będą dwa raporty dotyczące sytuacji młodzieży w Polsce. Pierwszym jest opracowany na zlecenie Kancelarii Premiera raport Młodzi 2011 ${ }^{4}$, który jest kopalnią wiedzy o charakterze wielowymiarowym, dotyczącej zarówno cech socjologicznych młodego pokolenia, jak i sytuacji edukacyjnej, zdrowotnej, nastawienia związanego z budowaniem własnej pozycji na rynku pracy czy wobec rodziny. Drugim jest raport z badania Konsumpcja substancji psychoaktywnych przez młodzież szkolna - Młodzież 2013 - zrealizowanego przez Fundację Centrum Badania Opinii Społecznej w 2013 roku i sfinansowanego przez Krajowe Biuro ds. Przeciwdziałania Narkomanii. W tym badaniu uczestniczyła młodzież ostatnich klas szkół ponadgimna-

3 Jan Paweł II, List apostolski Parati semper do młodych całego świata z okazji Międzynarodowego Roku Młodzieży, Rzym, 31 III 1985, 1, http://www.opoka.org.pl/biblioteka/W/ WP/jan_pawel_ii/listy/parati.html (18.08.2015).

4 Por. K. Szafraniec, Młodzi 2011, red. M. Boni, Warszawa 2011 [dalej: Młodzi 2011]. 
zjalnych. W każdej klasie badaniem objęto wszystkich obecnych w dniu realizacji sondażu: łącznie 1360 uczniów. Wywiady z nimi zostały zrealizowane metodą audytoryjną - uczniowie, samodzielnie i anonimowo, wypełniali ankiety w czasie jednej godziny lekcyjnej5.

\section{Portret społeczny}

Istnieją dwie powszechne tendencje w opiniach o młodzieży: tendencja do idealizowania, która ma swoją starą tradycję, bo zawsze w młodym pokoleniu dopatrywano się czegoś, za czym tęskniło pokolenie dorosłe, czego nie udało się dokonać pokoleniu schodzącemu, chce ono więc, by ich dzieci, ich następcy zrobili to lepiej, poprawili ich błędy, budowali lepszą przyszłość. Druga to tendencja do deprecjonowania - młodzi bywają postrzegani jako zagrożenie, a narzekanie na młodzież jest od wieków czymś normalnym. Trzeba przyznać, że młodzież jest zawsze inna niż ludzie dorośli. Przede wszystkim jest bardziej witalna, a przez to skłonna do najróżniejszych przygód. Młodzi mają też o wiele mniejszy bagaż doświadczeń życiowych niż dorośli. Wszystkie zdobyte przez nich doświadczenia pochodzą z czasów mniej odległych niż te doświadczenia, jakie zdobyli ludzie dorośli. Młodzież odzwierciedla świat taki, jakim on jest. Jeśli mówimy, że młodzież jest zła, to należy dodać: świat, w którym żyjemy, jest taki, bo właśnie tak prezentuje go współczesna młodzież ${ }^{6}$.

Czasy, w których przyszło żyć dzisiejszemu młodemu pokoleniu, pod wieloma względami nie należą do łatwych. Obserwując współczesne przemiany, trudno oprzeć się wrażeniu, że z każdym mijającym rokiem rzeczywistość wokół nas nabiera coraz większego tempa. Chcemy mieć coraz nowsze i lepsze urządzenia - komputery, tablety, smartfony. Pragniemy szybciej podróżować, szybciej przesyłać i otrzymywaćinformacje. Dążymy do tego, by mieć „więcej” i „szybciej” - te dwa krótkie słowa urosły do

5 Por. Centrum Badania Opinii Społecznej, Młodzież 2013, Warszawa 2014, www.cinn.gov. pl/portal?id=15\&res_id=673746 (19.06.2015) [dalej: Młodzież 2013].

6 Por. K. Pawlina, Religijność polskiej młodzieży, http://www.katolik.pl/religijnosc-polskiej-mlodziezy,1156,416,cz.html (13.08.2015). 
miana haseł przewodnich społeczeństwa XXI wieku. Stajemy się coraz bardziej zabiegani, zapracowani, mamy coraz mniej czasu dla siebie, dla rodzin, dla własnych dzieci, także dla Boga ${ }^{7}$. Ponadto dokucza nam przeciążenie informacyjne. Napływ zbyt dużej ilości informacji udaremnia ich prawidłowe przetwarzanie przez odbiorców. W ten sposób informacja jest coraz częściej utożsamiana z wiedzą, trudną do zweryfikowania (np. tak przedstawiany jest obraz Kościoła), a społeczeństwo industrialne, opierające się na przemyśle, zmienia się na naszych oczach w społeczeństwo informacyjne ${ }^{8}$, w którym informacja staje się podstawowym czynnikiem przemian, wartością nabywaną na różne sposoby za określone środki (także w szkole i na studiach) - informacja staje się wartością ekonomiczną, rynkową, wymienialną. Nowoczesne środki przekazu informacji powodują, że różne dotąd cywilizacje oraz społeczeństwa lokalne przenikają się, komunikują ze sobą, a w konsekwencji upodabniają i tworzą globalną wioskę. Proces globalizacji, nie umniejszając jego pozytywnych wpływów, prowadzi do powstawania głębszych różnic w poziomie rozwoju krajów bogatych i biednych, a nadmierny rozrost organizacji oraz koncernów międzynarodowych przyczynia się do tego, że rządy zwłaszcza mniej zamożnych państw mogą tracić kontrolę nad polityką wewnętrzną i suwerennością krajuํ. Nierówności w roz-

7 Por. D. Belina, Młodzież nadzieją i wyzwaniem Kościoła. O potrzebie docenienia preewangelizacji i ewangelizacji w formacji chrześcijańskiej młodych Polaków, https://www.katecheta. pl/Archiwum/2014/Katecheta-7-2014/VERBA-DOCENT/Mlodziez-nadzieja-i-wyzwaniemKosciola-O-potrzebie-docenienia-preewangelizacji-i-ewangelizacji-w-fo (5.08.2015).

8 Por. L. Porębski, Wykluczenie cyfrowe i co dalej? Nowe technologie jako katalizator podziałów społecznych i bodziec dla cywilizacyjnego rozwoju, „Acta Universitatis Lodziensis. Folia Sociologica" (2014) nr 50, s. 90n; S. Zajączkowska-Jakimiak, Wiedza i technologia w erze globalizacji, [w:] Globalizacja. Mechanizmy i wyzwania, red. B. Liberska, Warszawa 2002, s. 85; W. J. Burszta, Globalizacja z perspektywy antropologii kultury, [w:] Globalizacja. I co dalej?, red. S. Amsterdamski, Warszawa 2004, s. 105n; J. S. Nowak, Społeczeństwo informacyjne - geneza i definicje, [w:] Społeczeństwo informacyjne. Krok naprzód, dwa kroki wstecz, red. P. Sienkiewicz, J. S. Nowak, Katowice 2008, s. 25-36.

9 Por. R. Borkowski, Globalizacja, cywilizacja, ponowoczesność, [w:] Globalopolis. Kosmiczna wioska, szanse i zagrożenia, red. R. Borkowski, Warszawa 2003, s. 11; M. McLuhan, Understanding media, Corte Madera, CA 2003, s. 43; T. Zasępa, Globalizacja- szansą czy zagrożeniem porzadku międzynarodowego?, „Roczniki Teologiczne” (2006) 8, s. 161-185; Z. Sareło, Postmodernizm w pigułce, Poznań 1998, s. 8. 
woju gospodarczym i konflikty powstające w różnych częściach globu przyczyniają się do masowych migracji ludności w poszukiwaniu lepszych warunków życia ${ }^{10}$.

Jak w takim układzie sił wygląda portret społeczny młodych Polaków i ich sytuacja socjalna? Młodzi są ważnym elementem społeczeństwa, bo ich energię można wykorzystać do budowania lepszej przyszłości. Z wielu diagnoz wynika jednak, że dzisiejsza młodzież nie tyle chce zmieniać świat, ile raczej się do niego zaadaptować. Część młodzieży zaczyna dostrzegać nieopłacalność zbyt ambitnych planów - zjawisko bezrobocia wśród absolwentów szkół wyższych, trud i koszty kształcenia - wszystko to wpływa na zmiany postaw wobec kształcenia. Powraca zainteresowanie wykształceniem zawodowym, szczególną popularnością w Polsce cieszą się na powrót kierunki techniczne ${ }^{11}$. W sytuacji ciągłych zmian i niejednoznacznego rozumienia terminów „zawód” i „praca” nieużyteczna zaczyna być zasada stosowana w poradnictwie zawodowym: „wybierz najpierw zawód, a później szkołę". Wzrasta zapotrzebowanie na pracowników „elastycznych”, którzy będą mogli pracować na różnych stanowiskach. Powoduje to także nadmierną podaż wykształcenia, co przy zmniejszającej się liczbie miejsc pracy prowadzi do paradoksalnej dewaluacji i rewaluacji dyplomów. Bez dyplomu szanse na rynku pracy maleją, ale posiadanie go nie daje gwarancji zatrudnienia. Dochodzą do tego także osobiste preferencje ludzi młodych, którzy wybierają zawody związane z tym, co chcieliby robić, a nie z tym, co robić będą mogli ${ }^{12}$. Bezrobocie jest dużym problemem w Polsce, także dla ludzi młodych, kończących swą edukację. Obecnie zmniejsza się postrzeganie wyjazdu za granicę jako najlepszego rozwiązania dla młodzieży - w latach 2004-2007 o wyjeździe za granicę w poszukiwaniu pracy myślało dwie trzecie 19-latków kończących szkoły ponadgimnazjalne. W badaniach z 2010 roku odsetek ten spadł do 14,2 proc. ${ }^{13}$.

10 Por. Eurostat, Migration and migrant population statistics, http://ec.europa.eu/eurostat/ statistics-explained/index.php/Migration_and_migrant_population_statistics (24.08.2015).

11 Por. Młodzi 2011, s. 45n.

12 Por. D. Wiśniewski, Aspiracje młodzieży ponadgimnazjalnej w kontekście zmian społeczno-kulturowych, Toruń 2012, s. 73.

13 Por. Młodzi 2011, s. 47. 
Z badań dotyczących sytuacji ekonomicznej polskiej młodzieży wynika, że takie formy zarobkowania jak stała praca, praktyki zawodowe czy też praca dorywcza stanową domenę chłopców oraz uczniów zasadniczych szkół zawodowych, choć zaznaczyć należy, że pracę dorywczą również stosunkowo często podejmują dziewczęta oraz uczniowie innych szkół. Przeciętnie polski uczeń dysponuje kwotą od 100 do 200 zł miesięcznie (ok. 24-50 euro). Większość uczniów fundusze na swoje potrzeby uzyskuje od rodziców lub innych członków rodziny. Niemała grupa młodzieży (38 proc.) finansuje swoje wydatki z pracy nieregularnej, dorywczej; zaledwie 4 proc. - z pracy stałej. Blisko co dziesiąty badany uzyskuje pieniądze z praktyk zawodowych (9 proc.) i dla porównywalnej grupy badanych (10 proc.) źródłem dochodu jest handel w internecie lub testowanie gier internetowych. Stosunkowo rzadko (6 proc.) pieniądze na własne cele pochodzą ze stypendiów uzyskiwanych w szkole. Inne źródła dochodu to: praca na własny rachunek, ogólnie - handel, interesy, praca sezonowa, a także różne typy rent - rodzinna, socjalna ${ }^{14}$.

Według badań obejmujących ostatnie klasy szkół ponadgimnazjalnych w 2013 roku zdecydowana większość uczniów mieszka z obojgiem rodziców. W rodzinach niepełnych wychowuje się ogółem 17 proc. młodych ludzi, przy czym gros z nich mieszka jedynie z matką. Bardzo rzadko zdarza się, aby faktycznym opiekunem był tylko ojciec. Nieliczni uczniowie mieszkają z kimś z dalszej rodziny, np. z babcią. Dorastanie w niepełnej rodzinie często wiąże się z gorszą sytuacją materialną. Uczniowie mieszkający tylko z jednym z rodziców swoje warunki oceniają gorzej niż uczniowie wychowujący się w pełnej rodzinie. Jako złe określa je 9 proc. badanych z rodzin pełnych i prawie dwukrotnie więcej uczniów mieszkających tylko z matką lub tylko z ojcem (16 proc.) $)^{15}$.

W perspektywie zaangażowania społecznego trzeba zauważyć, że coraz mniej jest dla polskiej młodzieży spraw obojętnych, a coraz więcej ważnych, są generacją barwną i wyrazistą, odbierającą świat i własne życie bardziej intensywnie. Przekłada się to na ich przekonania w dziedzinie etyki osobistej i społecznej.

14 Por. Młodzież 2013, s. 89n.

15 Por. Młodzież 2013, s. 73. 


\section{Portret etyczny}

W kontekście rozwoju etycznego polskiej młodzieży warto zwrócić uwagę i poznać ich przekonania i postawy zwłaszcza w odniesieniu do małżeństwa i rodziny, a także osobistej hierarchii wartości i akceptacji postaw o zabarwieniu hedonistycznym i konsumpcji używek.

Decydujący wpływ na postawy i decyzje młodzieży odnośnie do małżeństwa i rodziny ma praca. Wśród młodych Polaków panuje przekonanie, że związek małżeński i założenie rodziny nie może być aktem beztroski - w odczuciu większości plany tego rodzaju są poważnym wyzwaniem wymagającym zabezpieczenia finansowego, stałej pracy, perspektyw zakupu własnego mieszkania. Te i inne okoliczności sprawiają, że powszechną dziś strategią młodych jest odkładanie decyzji o formalizowaniu związków na koniec drugiej dekady życia i później. Mimo iż wciąż duży jest odsetek uważających, że ślub kościelny jest potrzebny, a nawet ważniejszy od cywilnego - tak uważa 82 proc. Polaków w wieku 18-26 lat - wzrasta liczba osób żyjących w związkach nieformalnych, tymczasowych, „na próbę" czy mieszkających wspólnie bez formalnego związania się ze sobą. Coraz więcej młodych ludzi dopuszcza także rozwody jako formę rozwiązywania konfliktów małżeńskich i rodzinnych, a wielodzietność nie jest preferowanym modelem przyszłej rodziny, jaką mieliby założyć dzisiejsi nasto-i dwudziestolatkowie ${ }^{16}$.

Opisywane trendy są wewnętrznie zróżnicowane i mają na ogół swoje odpowiedniki statusowo-środowiskowe: młodzież wiejska jest bardziej tradycyjna, wielkomiejska i dobrze wykształcona - zdecydowanie bardziej obyczajowo wyzwolona. Działają tu również inne czynniki. Wśród nich najbardziej istotny dotyczy płci. Kobiety są bardziej prorodzinne niż mężczyźni, ale też przejawiają bardziej liberalne odniesienie do alternatywnych form życia małżeńskiego i rodzinnego. Ważne są także czynnik religijny oraz ocena związku rodziców. Osoby religijne wyżej wartościują życie rodzinne i są przywiązane do jego tradycyjnych form. Im lepiej

16 Por. Młodzi 2011, s. 52-55. 
zaś młodzież ocenia związek rodziców, tym bardziej pozytywnie nastawia się do założenia własnej rodziny ${ }^{17}$.

W zakresie norm katolickiej etyki małżeńsko-rodzinnej panują wśród polskiej młodzieży ambiwalentne poglądy. Świadomość moralna młodych katolików co do małżeństwa i rodziny ulega procesom pluralizacji i relatywizacji. Młodzi czują się bardziej twórcami niż adresatami norm moralnych ${ }^{18}$. Z jednej strony tęsknią za wielką miłością, za nawiązywaniem i celebrowaniem stałych relacji (zaręczyny, ślub i przyjęcie weselne - tu wszystko odbywa się w zgodzie z tradycją religijną i społeczną), z drugiej zaś chcą uwolnić się od dawnych zasad dotyczących życia intymnego i norm zachowań seksualnych ${ }^{19}$. W badaniach z 2013 roku postaw młodzieży wobec kontaktów seksualnych, ujętych w ramach czterech aspektów, uzyskano następujące wyniki (wśród uczniów ostatnich klas szkół ponadgimnazjalnych):

- akceptacja seksu przedmałżeńskiego (vs. małżeństwa jako cezury pozwalającej na rozpoczęcie pożycia seksualnego) - 64 proc. za do 14 proc. przeciw;

- akceptacja seksu jako wyrazu uczucia poza instytucją małżeństwa 73 proc. za do 14 proc. przeciw;

- akceptacja przelotnych związków seksualnych (seksu w ujęciu hedonistycznym - jako źródła przyjemnych doznań, bez zobowiązań) 31 proc. za do 52 proc. przeciw;

- akceptacja głównie prokreacyjnej funkcji seksu w małżeństwie 24 proc. za do 59 proc. przeciw ${ }^{20}$.

Postawy młodych ludzi wobec kontaktów seksualnych, w aspektach podlegających ocenie, wskazują na obecność wysokiego poziomu akceptacji seksu przedmałżeńskiego i seksu będącego wyrazem uczucia poza instytucją małżeństwa. Mniej zwolenników, a więcej przeciwników ma obecnie seks w ujęciu hedonistycznym. Pogląd, według którego głównym celem seksu w małżeństwie jest prokreacja, ma relatywnie niewielu zwo-

17 Por. Młodzi 2011, s. 55.

18 Por. J. Mariański, Religijność młodzieży polskiej w procesie przemian, „Zeszyty Naukowe KUL" (2010) nr 2, s. 54.

19 Por. Młodzi 2011, s. 55n.

20 Por. Młodzież 2013, s. 133-135. 
lenników wśród młodych ludzi - opinię tę podziela mniej niżjedna czwarta badanych. Na uwagę zasługuje fakt, że chłopcy - zdecydowanie bardziej niż dziewczęta akceptujący seks jako źródło pozytywnych doznań, których warunkiem nie są ani miłość, ani małżeństwo - jednocześnie w większym stopniu niż dziewczęta opowiadają się za uznaniem prokreacji za główny cel seksu w małżeństwie. Jednym z najistotniejszych czynników różnicujących poziom permisywności młodych ludzi w kwestiach dotyczących kontaktów seksualnych jest religijność. Większa restrykcyjność w omawianych kwestiach związana jest z regularnym, przynajmniej cotygodniowym uczestnictwem w praktykach religijnych i z osobistą identyfikacją z wiarąa ${ }^{21}$. Blisko połowa (46 proc.) badanych zgodziła się także z opinią, że homoseksualizm nie jest rzeczą normalną i nie wolno go tolerować2

Wśród osiemnastolatków inicjację seksualną przeżyło już 46 proc. osób, wśród dziewiętnastolatków - 62 proc., natomiast w grupie dwudziestolatków - 84 proc. Według deklaracji badanych średni wiek inicjacji seksualnej wynosi w przypadku dziewcząt 16 lat i 10 miesięcy, natomiast dla chłopców - 16 lat i 6 miesięcy. Opóźnieniu inicjacji seksualnej sprzyjają również przede wszystkim czynniki związane z religijnością. Wśród młodych ludzi uczestniczących raz w tygodniu w praktykach religijnych, „pierwszy raz” ma za sobą 41 proc., podczas gdy wśród niepraktykujących odsetek ten wynosi 67 proc.; w przypadku młodzieży deklarującej wiarę w Boga „,bez żadnych wątpliwości” oraz niewierzącej odsetki te wynoszą odpowiednio 48 proc. i 68 proc. ${ }^{23}$.

Blisko dwie trzecie ogółu badanych potwierdza obecność w swoim środowisku osób, które zostały rodzicami przed ukończeniem 18 roku życia, a więcej niż co czwarty respondent potrafi wskazać kilka takich przypadków. Systematyczne zwiększa się liczba urodzeń pozamałżeńskich w Polsce - z 5 proc. w 1990 roku do ponad 20 proc. w 2009 roku (średnia dla UE to obecnie 40 proc.). Dotyczy to wyłącznie kobiet poniżej 30 roku życia, które często pozostają w nieformalnych związkach partnerskich,

\footnotetext{
1 Por. Młodzież 2013, s. 135n.

22 Por. Młodzież 2013, s. 94.

23 Por. Młodzież 2013, s. 137.
} 
a wśród nich nastolatki stanowią 16 proc. Głównym źródłem utrzymania ich oraz ich dzieci są rodzice, konkubenci oraz świadczenia socjalne, co określa warunki rozwojowe dziecka jako niekorzystne ${ }^{24}$.

Wszystkie porównywalne dane ukazują, że na szczycie hierarchii ważności dla młodych Polaków wciąż pozostaje rodzina - udane życie rodzinne jest podkreślane jako sprawa bardzo ważna zarówno przez dawne, jak i przez nowe młode pokolenie. Zdecydowanie najważniejszą osobą w domu jest dla młodych ludzi matka. To na jej wsparcie przede wszystkim mogą liczyć w trudnych chwilach (60 proc.), ona jest także autorytetem, na którego uznaniu najbardziej im zależy (47 proc.). Rola ojca w rodzinie wypada dość blado. Ojciec rzadko jest znaczącym partnerem do rozmów (14 proc.), jeszcze rzadziej towarzyszem w spędzaniu wolnego czasu (9 proc.) dla młodych ludzi ${ }^{25}$.

Polska młodzież prócz życia rodzinnego za ważne uważa także przyjaźń, szacunek, interesującą pracę i dbałość o brak nałogów - choć nie idzie to w parze ze spadkiem konsumpcji używek. Przed wieloma szkołami można zobaczyć liczne grupy uczniów stojących na chodnikach w czasie przerw lub po skończonych lekcjach i palących papierosy. Do regularnego palenia papierosów przyznaje się jedna piąta uczniów szkół ponadgimnazjalnych (liceów, techników, szkół zawodowych). Zdecydowanie częściej po papierosy sięgają ci uczniowie, których rodzice na stałe lub sezonowo pracują za granicą. W przypadku nadużywania alkoholu wyraźnie widać wpływ postaw religijnych młodzieży. Im silniej zaangażowani religijnie są uczniowie, tym rzadziej zgłaszają przypadki upijania się. W roku 2010 wśród badanych, którzy uczestniczyli w praktykach religijnych kilka razy w tygodniu, w miesiącu poprzedzającym sondaż upiło się 22 proc. (w 2010 roku - 25 proc.), a w grupie osób w ogóle nieuczestniczących w praktykach religijnych - 52 proc. (w 2010 roku - 75 proc.). Do kontaktu z narkotykami przyznaje się 18 proc. młodzieży pełnoletniej. Również tutaj czynnikiem chroniącym przed eksperymentowaniem z narkotykami jest udział w praktykach religijnych. W przypadku osób biorących udział w praktykach religijnych kilka razy w tygodniu mniej niż co dziesiąty uży-

24 Por. Młodzież 2013, s. 137, Młodzi 2011, s. 84.

25 Por. Młodzież 2013, s. 96n. 
wał narkotyków (9 proc.). Osoby, które deklarowały się jako głęboko wierzące, rzadziej sięgały po narkotyki (12 proc.) niż niewierzący (31 proc.) ${ }^{26}$.

Większą wagę do przyjemności życiowych niż do osiągania ważnych celów przywiązuje 43 proc. młodych w wieku 18-29 lat, sądząc, że są one miarą życiowego sukcesu (33 proc.). Jednak znacznie więcej, 57 proc. stwierdziło, że ważniejsze jest dążenie do życiowo istotnych aspiracji. Jakkolwiek preferencje dla hedonizmu są bardzo wyraźne wśród młodych Polaków, to nie są one na tyle ważne, by przesłaniać osiąganie ważnych życiowych celów ${ }^{27}$.

Młodzi Polacy z pewnością są ambitni i wytrwali w dążeniu do celu, przebojowi i zaradni, ponad połowa młodzieży przypisuje też sobie takie zalety jak skromność i oszczędność, choć tak naprawdę wolą życie przyjemne i beztroskie. Dziś, pod wpływem niepewnej przyszłości i trudniejszych realiów, częściej niż o błyskotliwej karierze i prestiżu młodzi ludzie myślą i cenią spokojne i bezpieczne życie, stabilną pracę, ciepłe relacje z najbliższymi przyjaciółmi i rodziną ${ }^{28}$.

\section{Portret religijny}

Mogłoby się wydawać, że głoszenie chrześcijańskich wartości w takim układzie społeczno-moralnym, gdy każdy próbuje wyznaczać własne normy i tworzyć sobie własną prawdę, zostanie potraktowane jako nieaktualne czy staroświeckie. Jednak nie możemy zapominać, że współczesność to także czas działania Ducha Świętego, czas należący do historii zbawienia, której punktem centralnym jest Chrystus. On złożył swoim uczniom obietnicę: „Ja jestem z wami przez wszystkie dni, aż do skończenia świata" (Mt 28, 20). Chrystus dotrzymuje obietnic. Jest obecny i działa w świecie, szczególnie poprzez swój Kościół, którego głównym zadaniem jest głosić dobrą nowinę o zbawieniu wszystkim narodom w każdym czasie. Po syntetycznym rozważeniu specyfiki socjalnej można przejść do anali-

26 Por. Młodzież 2013, s. 155-157, 161, 166-168.

27 Por. Młodzi 2011, s. 43n.

28 Por. Centrum Badania Opinii Społecznej, Młodzież 2010, Warszawa 2011, s. 9. 
zy religijności polskiej młodzieży, która zostanie przedstawiona głównie w świetle wspomnianych we wstępnie badań społecznych z 2013 roku ${ }^{29}$.

W świetle badań z pierwszej dekady XXI wieku Janusz Mariański pisał: „Młodzież polska znajduje się w polu napięć pomiędzy sekularyzacją i ewangelizacją, nie da się jej opisać w kategoriach jednorodnego faktu społecznego. Z jednej strony silne są procesy sekularyzacyjne (np. «odkościelnienie», kryzys przekazu wiary), z drugiej strony ważne są oddziaływania Kościoła katolickiego i innych wyznań chrześcijańskich oraz nowych ruchów religijnych na świadomość religijną młodych (ewangelizacja)"30.

Wyniki badań CBOS z roku 2013 wskazują, że 71 proc. polskiej młodzieży ostatnich klas szkół ponadgimnazjalnych deklaruje się jako wierzący. Wśród tej grupy 6 proc. ankietowanych uważa się za głęboko wierzących, a 65 proc. za wierzących; 18 proc. młodzieży określa się jako niezdecydowani, a 10 proc. jako niewierzący ${ }^{31}$. W porównaniu z wynikami z roku 1996 odsetek osób określających się jako głęboko wierzący pozostał na tym samym poziomie, natomiast o 9 proc. spadł odsetek uczniów postrzegających się jako wierzący (z 74 do 65 proc.). 04 proc. zwiększyła się liczba niezdecydowanych (z 14 do 18 proc.), aż dwukrotnie wzrosła liczba osób niewierzących (z 5 do 10 proc.).

Tendencja spadkowa uwidacznia się przy analizie danych pokazujących częstotliwość uczestnictwa młodzieży w praktykach religijnych. Od roku 1996 liczba osób deklarujących cotygodniowy udział we mszy świętej zmniejszyła się z 62 do 43 proc. Wzrosła natomiast liczba uczniów praktykujących nieregularnie - z 21 do 34 proc. oraz liczba osób niepraktykujących wcale - z 16 do 23 proc. $^{32}$. Wyniki badań z 2013 roku wskazują na tendencję do systematycznego spadku liczby uczniów określających się jako wierzący oraz na tendencję do trwałego zwiększania się liczby osób niezdecydowanych i niewierzących. Podobna sytuacja zachodzi przy analizie liczby młodych ludzi regularnie uczestniczących w praktykach religijnych Kościoła.

\footnotetext{
29 Por. Młodzież 2013, s. 109-120.

30 J. Mariański, Religijność młodzieży polskiej..., art.cyt., s. 39.

31 Por. Młodzież 2013, s. 109.

32 Por. Młodzież 2013, s. 112.
} 
Przedstawione wyniki badań nad religijnością młodzieży świadczą o tym, że zmiany zachodzące w społeczeństwie nie pozostają bez wpływu na religijność młodych Polaków. Wzrasta w polskim społeczeństwie liczba osób wkraczających w dorosłość, które nierzadko mimo udziału w szkolnej lekcji religii, a także w katechezie parafialnej przygotowującej do sakramentów inicjacji chrześcijańskiej nie spotkały Chrystusa, a co za tym idzie, nie weszły z Nim w głęboką zażyłośćs ${ }^{33}$. Trzeba wziąć też pod uwagę fakt, że od kilku lat wyraźnie maleje odsetek uczniów mówiących, że rodzice wymagają od nich chodzenia do kościoła (od 2008 roku zmniejszył się on z 48 do 39 proc.). Zdecydowanie najczęściej chodzenia do kościoła wymagają od dzieci rodzice na wsi, najrzadziej w największych miastach ${ }^{34}$.

Zauważa się z kolei wysoką korelację pomiędzy udziałem w szkolnej lekcji religii a przystępowaniem dzieci i młodzieży do sakramentów inicjacji chrześcijańskiej - do pierwszej spowiedzi i Komunii świętej oraz do bierzmowania. Poza nielicznymi wyjątkami wszystkie dzieci uczęszczające na religię w szkole przygotowują się w swych parafiach (wraz z rodzicami) do przyjęcia pierwszej Komunii Świętej. W przypadku bierzmowania najwyżej 8-10 proc. młodzieży uczęszczającej na religię w szkole rezygnuje z przystąpienia do niego lub odkłada na późniejszy czas.

Na lekcje religii w szkołach ponadgimnazjalnych (liceum, technikum, szkoły zawodowe) uczęszcza 89 proc. młodzieży i opinia dwóch trzecich z nich na temat katechezy jest pozytywna, z czego jedna trzecia badanych twierdzi, że chętnie chodzi na lekcje religii w szkole i że są one ciekawe i (34 proc.). Nieco większy odsetek ankietowanych (38 proc.) stwierdza, że lekcje religii nie wyróżniają się niczym szczególnym na tle pozostałych zajęć szkolnych (nie są gorsze, nie są też lepsze), natomiast w ocenie niewiele ponad jednej czwartej uczniów (28 proc.) lekcje religii są nudne i nic ważnego się na nich nie dzieje ${ }^{35}$. Zdecydowanie rzadziej w katechezie partycypują ci uczniowie, którzy w ogóle nie praktykują religij-

33 Por. Kongregacja ds. Duchowieństwa, Dyrektorium ogólne o katechizacji, Rzym, 15 sierpnia 1997 [dalej: DOK], s. 80.

34 Por. Młodzież 2013, s. 103n.

35 Por. Młodzież 2013, s. 119. 
nie, choć i wśród nich wyraźnie przeważają ci, którzy na lekcje religii jednak uczęszczają. W stosunku do tych osób coraz bardziej odczuwa się potrzebę preewangelizacji, której celem jest rozpalenie w nich zapału do poszukiwania wartości duchowych, prawdy o świecie i człowieku, wzniecenie głodu transcendencji poprzez świadectwo chrześcijańskie i odpowiednie relacje interpersonalne, interpretację osobistych doświadczeń oraz ukazywanie wiarygodności chrześcijaństwa i Kościoła katolickiego $^{36}$. Powstaje zatem pytanie o zasadniczy kierunek edukacji religijnej młodzieży w Polsce.

\section{Ewangelizować czy katechizować?}

Całościowy proces formacji chrześcijańskiej składa się z czterech następujących po sobie i uzupełniających się etapów ${ }^{37}$. Pierwszym z nich jest preewangelizacja, której celem jest rozpalenie zapału do poszukiwania wartości duchowych, prawdy o świecie i człowieku, wzniecenie głodu transcendencji poprzez świadectwo chrześcijańskie i odpowiednie relacje interpersonalne, interpretację osobistych doświadczeń oraz ukazywanie wiarygodności chrześcijaństwa i Kościoła katolickiego. Bez preewangelizacji, jak podkreśla Dyrektorium katechetyczne Kościoła katolickiego w Polsce, żadna „forma katechezy nie przyniesie oczekiwanych owoców”38. Drugim etapem jest ewangelizacja w sensie ścisłym, której początek określany jest przez dokumenty katechetyczne jako „pierwsze głoszenie”, dokonuje się ono - w ramach nowej ewangelizacji - poprzez głoszenie kerygmatu (inaczej: katechezę kerygmatyczną), w którego centrum znajduje się osoba Chrystusa i Jego zbawcze misterium (por. DOK 61). Głównym celem ewangelizacji jest wezwanie do nawrócenia, dlatego skierowane jest ono przede wszystkim do niewierzących i obojętnych religijnie. Trzecim elementem

36 Por. P. Mąkosa, Preewangelizacja pierwszym i koniecznym etapem formacjichrześcijańskiej, „Katecheta” (2010) nr 7-8, s. 25-34.

37 Por. P. Mąkosa, Katecheza młodzieży w Polsce. Stan aktualny i perspektywy rozwoju, Lublin 2009, s. 531-533; D. Belina, Młodzież nadzieją i wyzwaniem Kościoła..., art. cyt. (5.08.2015).

38 Konferencja Episkopatu Polski, Dyrektorium katechetyczne Kościoła katolickiego w Polsce, Kraków 2001 [dalej: PDK], s. 13. 
formacji chrześcijańskiej jest katecheza mistagogiczna (przygotowująca do przyjęcia sakramentów i wyjaśniająca je), określana w dokumentach katechetycznych jako katecheza wtajemniczająca (por. DOK 64-68). Warunkiem jej skuteczności jest wcześniejsze nawrócenie katechizowanego. Dokumenty katechetyczne zwracają uwagę, iż ze względu na wymiar liturgiczny i wspólnotowy katechezy mistagogicznej najbardziej odpowiednim miejscem dla niej jest parafia (por. DOK 67n; PDK 25). Czwartym elementem integralnej formacji chrześcijańskiej jest katecheza stała (stałe wychowanie wiary), przekazująca syntezę depozytu wiary, prowadząca do stopniowego uchwycenia całej prawdy o planie Bożym oraz rozwijająca i podtrzymująca, w łonie wspólnoty chrześcijańskiej, stały proces nawrócenia osoby (por. DOK 69, 85). Nauczanie religii w szkole ze względu na własną specyfikę zostało potraktowane przez autorów dokumentów katechetycznych jako osobna forma posługi słowa, różniąca się od katechezy w sensie ścisłym. Jego szczególnym zadaniem jest wychowanie chrześcijańskie oraz przekaz nauki wiary (por. DOK 73; PDK 83).

W środowisku polskim główną wagę przykłada się do dwóch etapów formacji chrześcijańskiej dzieci i młodzieży.Jednym z nich jest katecheza mistagogiczna odbywająca się w parafii przed przyjęciem sakramentów Eucharystii oraz pokuty i pojednania przez dzieci w pierwszych latach szkoły podstawowej, a następnie przed przyjęciem sakramentu bierzmowania przez młodzież w ostatniej klasie gimnazjum lub w pierwszej szkoły ponadgimnazjalnej. Drugim natomiast jest katecheza systematyczna, utożsamiana z nauczaniem religii w szkole, czyli dwie godziny lekcyjne tygodniowo w modelu fakultatywnym. Istnieje także katecheza realizowana poprzez grupy, ruchy oraz stowarzyszenia katolickie działajace w parafii. Preewangelizacja i ewangelizacja odbywają się zasadniczo w ramach rekolekcji szkolnych lub wyjazdowych bądź też przy zaangażowaniu szkół nowej ewangelizacji. Ma też miejsce podczas szkolnych lekcji religii. Stąd też można śmiało postawić tezę, iż powyższe działania zawierają w sobie bądź w określonym stopniu przyczyniają się do realizacji celów wszystkich czterech etapów procesu formacji chrześcijańskiej.

Wielu kapłanów i katechetów uczących w szkołach lub przygotowujących dzieci i młodzież do przyjęcia sakramentów zakłada wciąż, że uczniowie wynoszą wiarę z domów. Tymczasem wspomniane wyżej czynniki 
społeczne sprawiają, że nie zawsze tak jest. Bywa, że podstawowa socjalizacja religijna (będąca w istocie preewangelizacją) następuje na innych drogach - najpierw poprzez nawiązanie relacji z katechetą w szkole, potem dzięki działalności duszpasterzy w parafii, a następnie także przez spotkania i wyjazdy z animatorami ruchów i stowarzyszeń młodzieżowych. Przywołane we wstępie wydarzenia religijne podczas wakacji są tego najlepszymi dowodami - ukazują, że właśnie tam ma miejsce intensywna działalność ewangelizacyjna. Choć nie zawsze przekłada się to na trwałą postawę zaangażowania w życie parafialne, które w oczach młodych ludzi może się wydawać mniej atrakcyjne niż ewangelizacja wakacyjna, to jednak przyczynia się do rozwoju duchowego i moralnego polskiej młodzieży, spaja ją, ukazuje moc wspólnoty i modlitwy.

W Polsce istnieją także inne formy przyciągnięcia do Kościoła dzieci i młodzieży. Jedną z nich jest działalność sportowa. W 2000 roku podczas spotkania ze sportowcami całego świata św. Jan Paweł II powiedział: „Sport ujawnia bowiem nie tylko bogate możliwości fizyczne człowieka, ale także jego zdolności intelektualne i duchowe"39. Parafialne grupy oraz kluby różnych dyscyplin sportowych są szansą zbliżenia do Kościoła dzieci i młodzieży wywodzących się z rodzin, w których rodzice są obojętni religijnie, a także niewierzący. Wśród przykładów można wymienić: Parafialny Klub Sportowy „Jadwiga” działający od 1992 roku przy parafii św. Jadwigi Królowej w Krakowie ${ }^{40}$ czy Parafialny Klub Sportowy „Radość” działający od 1996 roku w Warszawie przy parafii Matki Bożej Anielskiej ${ }^{41}$.

Innym środowiskiem jest harcerstwo, które w 2012 roku obchodziło jubileusz 100-lecia swego istnienia w naszym kraju. Grupy harcerskie oprócz proponowania różnego rodzaju zajęć, gier i zabaw czynnie promują wartości chrześcijańskie. Harcerze działają niejednokrotnie przy parafiach: współorganizują Dzień Papieski, czuwają przy Grobie Pańskim

39 Jan Paweł II, Przemówienie podczas spotkania ze sportowcami całego świata z okazji międzynarodowego sympozjum na temat: Oblicze i dusza sportu w roku Wielkiego Jubileuszu, Rzym, 28 października 2000, http://www.sport.episkopat.pl/dokumenty/?type=jp2\&id=10 (18.08.2015).

40 Por. Parafialny Klub Sportowy "Jadwiga”, http://www.pksjadwiga.com (19.08.2015).

${ }_{41}$ Por. Parafialny Klub Sportowy „Radość” Warszawa, http://pksradosc.futbolowo.pl (19.08.2015). 
w Wielki Piątek czy uczestniczą aktywnie w procesji Bożego Ciała - o wielu rozmaitych akcjach charytatywnych i pomocowych nie wspominając. Do najbardziej znanych grup harcerskich w Polsce współpracujących z Kościołem należą: Stowarzyszenie Harcerstwa Katolickiego „Zawisza” ${ }^{42}$, Związek Harcerstwa Polskiego oraz Związek Harcerstwa Rzeczypospolitej.

Obok tych działań należy zwrócić szczególną uwagę na nauczanie religii w szkole. Wyżej zostało wspomniane, że dwie trzecie uczniów uczęszczających na te zajęcia pozytywnie ocenia jakość lekcji religii w szkole. Warto więc poszukać odpowiedzi na pytanie o czynniki, które sprawiają zarówno, że uczęszczają oni na te lekcje, jak i że z nich rezygnują. Co ma w tym procesie kluczowe znaczenie?

Istnieje kilka czynników, które wpływają na decyzje dotyczące rezygnacji z uczestnictwa w lekcjach religii. $\mathrm{W}$ analizie tego problemu często winą obarcza się katechetę. Jeżeli lekcje są nudne, prowadzone w sposób autorytarny, uczeń nie ma możliwości swobodnej wypowiedzi - wówczas odchodzi, uważając, że uczestnictwo w takiej lekcji to strata czasu. Warto jednak zaznaczyć, że osoba nauczyciela to nie jedyny czynnik wpływający na taką decyzję. Istotne znaczenie mają współczesne przekazy medialne, które coraz częściej i coraz dobitniej kreują negatywny obraz katechezy i Kościoła. Media, zwłaszcza internet, są dla uczniów bardziej wiarygodne, stąd przekazywane przez nie treści często prowadzą do konfliktów pomiędzy uczniem a nauczycielem. Współczesnemu młodemu człowiekowi trudno jest zrozumieć i przyjąć nauczanie Kościoła, które odbierane jest jako zaściankowe. Problem dotyczy głównie etyki seksualnej i małżeńskiej. Uczniom trudno jest przyjąć, że nauki Kościoła nie można traktować wybiórczo. Podchodzą oni raczej do niej, jakby „nauka Kościoła” była nazwą alejki w światopoglądowo-religijnym supermarkecie i przechodząc nią, wkładają do koszyka tylko koniecznie potrzebne rzeczy oraz te, które im się podobają; reszta zostaje na półkach. Przyjmują więc to, co jest wygodne, a to, co im nie odpowiada, odrzucają (np. uczeń mówi

${ }^{42}$ W stosunku do Stowarzyszenia Harcerstwa Katolickiego „Zawisza” od jakiegoś czasu używa się również nazwy Skauci Europy, ponieważ należy ono do Federacji Skautingu Europejskiego, zrzeszającego chrześcijańskich harcerzy i skautów z ponad 20 krajów europejskich. Polska strona internetowa SHK „Zawisza” dostępna jest pod adresem: http://skauci-europy.pl (13.08.2015). 
na lekcji religii, że jest katolikiem, wierzy w Boga, ale nikt go nie zmusi do przestrzegania „tego, co Kościół wymyślił”). Wielu mimo to uczęszcza na lekcje religii, ale są i tacy, którzy odchodzą, stwierdzając, że mają własne zdanie i nie będą go zmieniać pod wpływem nauczyciela religii.

Innym czynnikiem wpływającym na rezygnację jest zyskanie wolnego czasu, zwłaszcza jeśli katecheza jest na pierwszej lub ostatniej lekcji można wcześniej wrócić do domu, wykorzystać ten czas na realizowanie hobby itd. (np. uczeń mówi, że zwolnił się z wychowania fizycznego i z religii, przez co uzyskał dodatkowych 5 godzin wolnych w tygodniu). Wynika to z niekorzystnego zapisu w rozporządzeniu MEN w sprawie warunków i sposobu organizowania lekcji religii w publicznych szkołach i przedszkolach ${ }^{43}$ zakładającego, iż przedmiotem alternatywnym do religii jest etyka, z tym że możliwa jest rezygnacja z obu tych przedmiotów; w przypadku uczniów pełnoletnich następuje to na ich życzenie.

Jest jeszcze jedno zjawisko, które zaczyna nabierać coraz większego znaczenia i stanowi powód do niepokoju. Od pewnego czasu niechodzenie na religię stało się modne: „ty nie chodzisz - to ja też nie będę”, co dodatkowo wzmacniane jest przez presję tych, którzy nie chodzą, wywieraną na uczestnikach lekcji religii. Ogólnie rzecz biorąc, trzeba zwrócić również uwagę na to, że ci, którzy rezygnują, to wciąż są jednostkowe przypadki (nie wliczając uczniów innych wyznań lub niewierzących), a największy wpływ, mimo wszystko, na takie postępowanie ma religijność wyniesiona z domu (np. w klasach, gdzie ksiądz prowadzi lekcje religii w stylu bardzo autorytarnym, znaczna liczba uczniów wypisała się, ale reszta została, mimo że byli traktowani w sposób instrumentalny).

\section{Wnioski}

Kilka lat temu Tadeusz Szawiel prognozował spowolnienie zmian w praktykach religijnych i religijności Polaków w ogóle. Jego zdaniem mają na to wpływ trzy istotne czynniki. Po pierwsze, polska transformacja ustrojowa nie naruszała istniejących więzi społecznych w stosun-

43 Dz.U. z 1999 r. Nr 67, poz. 753. 
kowo stabilnych społecznościach lokalnych (dla wiary religijnej ważna jest pewnego rodzaju kontrola społeczna). Po drugie, sprawnie działające instytucje kościelne, przede wszystkim na poziomie parafialnym, pozwalają na zachowanie identyfikacji religijnej. Po trzecie wreszcie, lekcje religii w szkole w skali masowej podtrzymywały, pobudzały i nadal podtrzymują motywacje religijne ${ }^{44}$.

W perspektywie przedstawionych badań można z pewnością zauważyć wpływ wymienionych przez Szawiela czynników na utrzymanie względnie stabilnego poziomu wierzeń i praktyk religijnych w Polsce. Niemniej zauważalny jest również wpływ modernizacji i globalizacji na negatywne przemiany w religijności polskiej młodzieży i rodzin, w których ona dorasta. Widoczne są bowiem przejawy tendencji, według której część młodych Polaków nie do końca uświadamia sobie, co rzeczywiście oznacza wyrażenie,,być katolikiem”. Znajdują się oni w niestabilnym i poniekąd ulotnym stadium swojego rozwoju religijnego. Przy tym charakterystyczne jest, iż niechętnie przyznają się do tej,,bezdomności” wyznaniowej, nawet jeżeli ich więzi z określonym wyznaniem czy religią są bardzo osłabione, niemal żadne, a katolickość bardzo niejasna i nieokreślona ${ }^{45}$. Przejawia się to zazwyczaj w postaci niskiego poziomu wiedzy religijnej związanej z deklarowanym wyznaniem (przybiera niekiedy postać analfabetyzmu religijnego), i to pomimo uczęszczania na lekcje religii w szkole. Nieznajomość prawd wiary prowadzi z kolei do zaniku praktyk religijnych lub też do ich magicznego traktowania. W dalszej konsekwencji przyczynia się do niedojrzałości duchowej i infantylizmu religijnego. Co ważne, uniemożliwia integralny rozwój katechizowanej młodzieży ${ }^{46}$.W perspektywie procesu wychowania religijnego oznacza to potrzebę poszukiwania nowych sposobów pracy wychowawczej i edukacyjnej na polu wiedzy i postaw religijnych młodzieży. „Wszelkie oddziaływanie, tym bardziej religijne, zaczyna się od relacji, buduje się na spotkaniu. By dzielić się wia-

4 Por. T. Szawiel, Religijna Polska, religijna Europa,„Więź” (2008) nr 9, s. 32n.

45 Por. J. Mariański, Religijność młodzieży polskiej..., art.cyt., s. 43.

46 Por. A. Zellma, Analfabetyzm religijny polskiej młodzieży wyzwaniem dla szkolnego nauczania religii, „Katecheta” 2013, nr 7-8, https://www.katecheta.pl/Archiwum/2013/Katecheta-7-2013/ VERBA-DOCENT/Analfabetyzm-religijny-polskiej-mlodziezy-wyzwaniem-dla-szkolnegonauczania-religii (6.08.2015). 
rą, trzeba najpierw być, dalej - poznawać, rozmawiać, tworzyć okazję do wspólnych przeżyć, dawać świadectwo, ale też cieszyć się wiarą swych wychowanków, zauważać, doceniać ją i umacniać" ${ }^{47}$. Tożsamość religijna Polaków wiąże się bowiem w dalszym ciągu najczęściej z przynależnością wyznaniową do Kościoła katolickiego, dzieci najczęściej dziedziczą przynależność wyznaniową po rodzicach. Przezwyciężenie katolickiego monopolu na religijność dokonuje się w społeczeństwie polskim bardzo powoli. W młodym pokoleniu zaznacza się już wyraźniej niż w pokoleniu ludzi dorosłych opór wobec autorytarnych sposobów sprawowania władzy w Kościele. Młodzi Polacy coraz częściej traktują ofertę Kościoła jako propozycję, którą można i należy zbadać w świetle własnych kompetencji oraz przyjąć ją lub odrzucić.

Potrzebne jest zatem ze strony duszpasterzy i katechetów zaangażowanie młodych ludzi w tworzenie klimatu spotkania z Bogiem w Kościele i rzetelnej dyskusji o wierze i moralności podczas szkolnej lekcji religii i spotkań parafialnych. Trzeba wysłuchiwać racji ludzi młodych oraz ukazywać im argumenty na rzecz stanowiska Kościoła, by nie wydawało im się ono jedynie słuszną normą, narzuconą im siłą z góry - tę bowiem z zasady odrzucą. Promocja pozachrześcijańskich stylów myślenia i działania domaga się dziś takiej formy dotarcia do ludzi młodych, która pozwoli im poczuć się prawdziwie wolnymi, mającymi wybór pomiędzy chrześcijańską a niechrześcijańską wizją świata, przy czym ta pierwsza winna być ukazana jasno i wyraźnie wraz z całym pięknem przesłania ewangelicznego, które w sobie zawiera.

Kluczem do sukcesu całego procesu formacji i edukacji religijnej w Polsce jest osobiste doświadczenie Boga - spotkanie w swoim życiu Chrystusa. Wiara, będąca przez wiele lat wartością narodową, kulturową, była też wartością dziedziczną, przekazywaną w domu i w narodzie jako coś oczywistego, jako społeczna potrzeba. Diagnozy socjologiczne wcześniejsze i najnowsze - mówią o pewnych zmianach religijności, ale nie mówią o upadku religijności w przyszłej Polsce. Te zmiany polegają

${ }_{47}$ R. Chałupniak, Religijny analfabetyzm młodzieży, ,Katecheta” (2013) nr 7-8, https://www. katecheta.pl/Archiwum/2013/Katecheta-7-2013/Forum-katechety/Religijny-analfabetyzmmlodiezy?o=1 (6.08.2015). 
głównie na przejściu od religijności dziedziczenia do religijności przeżywanej i osobiście wybieranej. Religijność przestaje być dla młodzieży wyraźną i oczywistą wartością tradycyjną, ale bez wątpienia staje się dla nich coraz bardziej doświadczeniem osobistym. Oznacza to, że jeśli ktoś urodził się w rodzinie wierzacej, to wiara nie zawsze zostaje mu przekazana automatycznie. Dziś młody człowiek sam chce decydować i wybierać. Następuje przejście od religijności dziedziczenia do religijności jako wartości osobistej. Nie przewiduje się jednak gwałtownego odwrotu od religii, ale trzeba podkreślić, że nie będzie ona przekazywana wyłącznie przez tradycję, lecz bardziej przez osobisty wybór. Świadoma osobista decyzja - to kierunek przyszłości ludzi wierzących. W warunkach kształtowania się społeczeństwa pluralistycznego wiara nie będzie tylko sprawą urodzenia. Środowisko społeczne nie będzie gwarancją przekazywania wiary. Będzie ona przede wszystkim wyrazem świadomej i osobistej decyzji ${ }^{48}$.

$$
*^{* *}
$$

W młodości jest moc przemiany. Młodzi są jak łąka na wiosnę. Po zimie może być na łące dużo rozkładających się resztek. Ale w wiośnie jest taka siła, która to wszystko przezwycięży. Zieleń trawy pokonuje zimową szarość, a kwiaty wyrastają nawet na pozostałych po zimie resztkach. W młodzieży jest ogromna siła. Współczesna młodzież w życiu najbardziej ceni wolność, sprawiedliwość, miłość i uczciwość. To wszystko znajduje się w Ewangelii. Te tęsknoty młodzieży są więc rodem z Ewangelii. Odrzucając formy manifestacji i życia Kościoła, nie odrzucają samej Ewangelii. Trzeba więc szukać innych, nowych sposobów wyrażania się Kościoła - takich, w których młody Kościół będzie czuł się ,jak u siebie”. Kierunek ewolucji religijności zmierza od form obrzędowości do osobistego doświadczenia i z powrotem. Nowe podejście do religii będzie wiązać się bardziej $z$ doświadczeniem religijnym niż apriorycznym przyjęciem nauczania Kościoła. Młody człowiek we współczesnej cywilizacji uznaje za swoje tylko to, czego sam doświadczył, co przeżył, co stało się jego udziałem.

48 Por. J. Mariański, Religijność młodzieży polskiej..., art. cyt., s. 40-43; K. Pawlina, Religijność polskiej młodzieży, art.cyt. (13.08.2015). 
Również w kwestiach wiary ważne jest przede wszystkim to, co przeżywa i czego doświadcza, inaczej formy obrzędowości będą go męczyć, bo są mu obce. Gdy jednak staną się one osobistym doświadczeniem spotkania z Bogiem, na powrót staną się wartością. Niebezpieczeństwem jest z pewnością wybiórcze traktowanie nauki Kościoła przez młodych katolików, którzy nie tracąc jeszcze poczucia przynależności religijnej, zdają się stać na rozdrożu, a w przypadku konfliktów moralnych są skłonni do odrzucenia norm kościelnych en bloc. Kluczowe dla przyszłości polskiego Kościoła wydają się działania ewangelizacyjne, prowadzone w ramach szkolnej i pozaszkolnej pracy z dziećmi i młodzieżą, a także z ich rodzinami, mające na celu budowanie wspólnoty zdolnej podtrzymać i kultywować przyjęte normy i zwyczaje oraz umożliwiającej dojrzewanie wiary młodego pokolenia. 


\title{
Summary
}

\author{
Społeczne, etyczne i religijne postawy polskiej młodzieży \\ oraz ich konsekwencje dla nauczania religii w Polsce
}

Artykuł, odwołując się do badań socjologicznych z ostatnich kilku lat, charakteryzuje polską młodzież pod względem przyjmowanych wartości społecznych, etycznych i religijnych, by ukazać ważne konsekwencje dla nauczania religii w Polsce. 25 lat od momentu, kiedy lekcje religii na nowo pojawiły się w polskich szkołach, zachęca do różnych podsumowań, wyciągania wniosków i kreślenia perspektyw. Tekst podkreśla stojącą przed Kościołem szansę, jaką w udzielaniu młodym wsparcia w podejmowanym wysiłku wzrostu duchowego daje szkolna katecheza. W sytuacji globalnych przemian, które mają wpływ na myślenie i sposób postępowania młodzieży, dużą wagę należy przypisać działaniom wychowawczym, które będą wyzwalać osobiste doświadczanie miłości Boga. Kluczowe dla przyszłości polskiego Kościoła wydają się działania ewangelizacyjne, prowadzone w ramach szkolnej i pozaszkolnej pracy z dziećmi i młodzieżą w celu podtrzymywania i kultywowania przekonań religijnych i zwyczajów oraz umożliwiania dojrzewania wiary młodego pokolenia.

Słowa kluczowe: Polska, młodzież, religia, etyka, ewangelizacja

\section{Social, Ethical and Religious Attitudes of Polish Youth and the Implications for Teaching Religion in Poland}

It is 25 years since when religious education was reestablished in Polish public and private schools. This anniversary encourages for various summaries, drawing conclusions and drafting perspectives. Referring to sociological research of the past few years, the article depicts Polish youth in terms of acquired social, ethical and religious values in order to show important implications for the transmission of religiosity in Poland. The text emphasizes the opportunities the Church is offered by school religious instruction (becoming also catechesis) in providing the youth support for spiritual growth. In case of global changes affecting the youth style of living, greater importance should be attributed to educational activities that will trigger personal experience of God's love. The evangelization activities carried out within the framework of school education and extracurricular work with children and young people seem to be key factor for the future of the Polish Church as a community that is able to sustain and cultivate religious beliefs and customs allowing thus the maturation of the young generation faith.

Keywords: Poland, youth, religion, ethics, evangelization 


\section{Bibliografia}

Belina D., Młodzieżnadziejąi wyzwaniem Kościoła. 0 potrzebie docenienia preewangelizacji i ewangelizacji w formacji chrześcijańskiej młodych Polaków, https://www.katecheta.pl/ Archiwum/2014/Katecheta-7-2014/VERBA-DOCENT/Mlodziez-nadzieja-i-wyzwaniemKosciola-O-potrzebie-docenienia-preewangelizacji-i-ewangelizacji-w-fo (5.08.2015).

Borkowski R., Globalizacja, cywilizacja, ponowoczesność, [w:] Globalopolis. Kosmiczna wioska, szanse i zagrożenia, red. R. Borkowski, Warszawa 2003, s. 7-28.

Burszta W. J., Globalizacja z perspektywy antropologii kultury, [w:] Globalizacja. I co dalej?, red. S. Amsterdamski, Warszawa 2004, s. 101-117.

Centrum Badania Opinii Społecznej, Młodzież 2010, Warszawa 2011.

Centrum Badania Opinii Społecznej, Młodzież2013, Warszawa 2014, www.cinn.gov. pl/portal?id=15\&res_id=673746 (dostęp: 19.06.2015).

Chałupniak R., Religijny analfabetyzm młodzieży, ,Katecheta” (2013) nr 7-8, https:// www.katecheta.pl/Archiwum/2013/Katecheta-7-2013/Forum-katechety/Religijnyanalfabetyzm-mlodiezy?o=1 (6.08.2015).

Eurostat, Migration and migrant population statistics, http://ec.europa.eu/eurostat/statistics-explained/index.php/Migration_and_migrant_population_statistics (24.08.2015).

Jan Paweł II, List apostolski Parati semper do młodych całego świata z okazji Międzynarodowego Roku Młodzieży, Rzym, 31 marca 1985, http://www.opoka.org. pl/biblioteka/W/WP/jan_pawel_ii/listy/parati.html\# (18.08.2015).

Jan Paweł II, Przemówienie podczas spotkania ze sportowcami całego świata z okazji międzynarodowego sympozjum na temat: Oblicze i dusza sportu w roku Wielkiego Jubileuszu, Rzym, 28 października 2000, http://www.sport.episkopat.pl/ dokumenty/?type=jp2\&id=10 (18.08.2015).

Kancelaria Prezesa Rady Ministrów, Młodzi 2011, red. M. Boni i in., Warszawa 2011.

Konferencja Episkopatu Polski, Dyrektorium katechetyczne Kościoła katolickiego w Polsce, Kraków 2001.

Kongregacja ds. Duchowieństwa, Dyrektorium ogólne o katechizacji, Rzym, 15 sierpnia 1997.

Mariański J., Religijność młodzieży polskiej w procesie przemian, „Zeszyty Naukowe KUL” (2010) nr 2, s. 39-61.

Mąkosa P., Katecheza młodzieży w Polsce. Stan aktualny i perspektywy rozwoju, Lublin 2009.

Mąkosa P., Preewangelizacja pierwszym i koniecznym etapem formacji chrześcijańskiej, „Katecheta” (2010) nr 7-8, s. 25-34.

McLuhan M., Understanding media, Corte Madera, CA 2003.

Nowak J. S., Społeczeństwo informacyjne - geneza i definicje, [w:] Społeczeństwo informacyjne. Krok naprzód, dwa kroki wstecz, red. P. Sienkiewicz, J. S. Nowak, Katowice 2008, s. 25-48.

Pawlina K., Religijność polskiej młodzieży, http://www.katolik.pl/religijnosc-polskiej-młodziezy,1156,416,cz.html (13.08.2015). 
Porębski L., Wykluczenie cyfrowe i co dalej? Nowe technologiejako katalizator podziałów społecznych i bodziec dla cywilizacyjnego rozwoju, „Acta Universitatis Lodziensis. Folia Sociologica" (2014) nr 50, s. 89-106.

Sareło Z., Postmodernizm w pigułce, Poznań 1998.

Szawiel T., Religijna Polska, religijna Europa,,Więż” (2008) nr 9, s. 5-37.

Wiśniewski D., Aspiracje młodzieży ponadgimnazjalnej w kontekście zmian społeczno-kulturowych, Toruń 2012.

Zajączkowska-Jakimiak S., Wiedza i technologia w erze globalizacji, [w:] Globalizacja. Mechanizmy i wyzwania, red. B. Liberska, Warszawa 2002, s. 84-101.

Zasępa T., Globalizacja - szansą czy zagrożeniem porządku międzynarodowego?, „Roczniki Teologiczne" (2006) 8, s. 161-185.

Zellma A., Analfabetyzm religijny polskiej młodzieży wyzwaniem dla szkolnego nauczania religii, „Katecheta” (2013) nr 7-8, https://www.katecheta.pl/Archiwum/2013/ Katecheta-7-2013/VERBA-DOCENT/Analfabetyzm-religijny-polskiej-mlodziezywyzwaniem-dla-szkolnego-nauczania-religii (6.08.2015). 